Archaeological Journal

\title{
Additional Notes on Leaden FontsThe Haresfield Bowl
}

\author{
Alfred C. Fryer Ph.D., M.A., F.S.A.
}

To cite this article: Alfred C. Fryer Ph.D., M.A., F.S.A. (1908) Additional Notes on Leaden FontsThe Haresfield Bowl, Archaeological Journal, 65:1, 287-288, DOI: 10.1080/00665983.1908.10853088

To link to this article: http://dx.doi.org/10.1080/00665983.1908.10853088

册 Published online: 17 Jul 2014.

Submit your article to this journal

Џ Article views: 2

Q View related articles $₫$ 
To reee page 287.

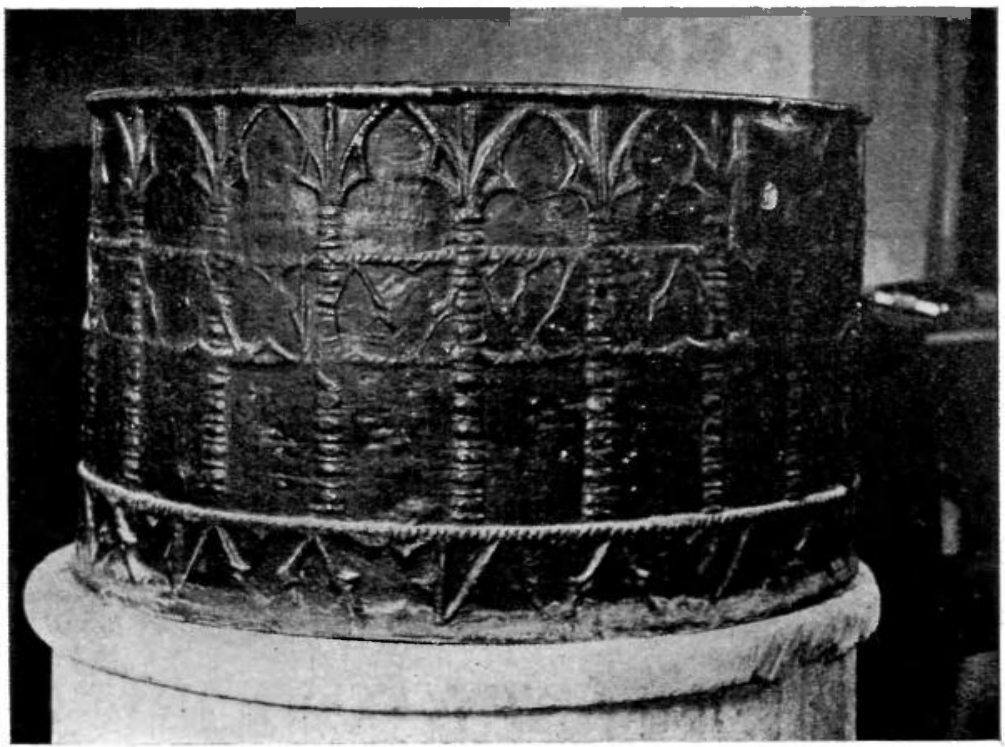

LEADES FOYT AT HARESFIELD, QLOUCESTERSHIRE. 


\title{
ADDITIONAL NOTES ON LEADEN FONTS. THE HARESFIELD BOWL. ${ }^{1}$
}

\author{
By ALGRED C. FRYER, Ph.D., M.A., F.S.A.
}

In a paper on "Leaden Fonts," printed in the Archoeological Journal for $1900,{ }^{2}$ I stated that the number of leaden bowls was twenty-seven. A little later two more were discovered; one was the circular bowl in Holy Trinity church, Penn, Buckinghamshire. This bowl was coated over with colour, and it was believed to be constructed of stone until, by an accident, it was found to be made of lead. The other was a rectangular vessel standing on the lawn of Greatham House, Pulborough, Sussex, and was doubtless discarded at the restoration of the adjacent church some forty years ago, when a new font was placed in the sacred edifice. The two fonts were duly recorded in the Archaeological Journal. ${ }^{3}$ So, with the Haresfield bowl, we appear to possess as many as thirty leaden fonts in England.

The font at Haresfield, Gloucestershire, has been an unsolved puzzle for many years (Fig. 1). This font has a diameter of 1 foot $10 \frac{1}{2}$ inches, and the external depth of the bowl is 1 foot $1 \frac{1}{2}$ inch. It is painted a dark green colour, and this appears to have deceived some authorities, who have placed it down as an example of a bell-metal font. I was permitted by the churchwarden to remove a small fraction of the material, and on submitting it to chemical analysis the fact is now established that the bowl is made of lead. The ornamentation has given rise to various conjectural dates being assigned to its construction. The bowl is adorned with twenty-two pointed arches having cuspings. These arches rest on shafts formed of some twenty-six beads. Round the centre and

1 Read before the Institute December 2nd, 1908.
2 See Arch. Journ., lvii, 40.

3 Arch. Journ., lxiii, 97. 
at the bottom of the bowl are bands of ornament composed of quatrefoils and triangles placed in squares. Mr. W. St. John Hope, M.A., Mr. Laurence Weaver, F.S.A., Mr. Bligh Bond and Dr. Alfred Harvey have come to the conclusion that this font is well in the Gothic period, and its construction may be assigned to the early years of the fourteenth century. The arches, the tracery and the cuspings are most unlikely to be post-Gothic, while the bands of ornamentation round the base and centre are similar to many parapets of fourteenth century work. ${ }^{1}$ The buttoned shafts present the chief difficulty. Mr. Hope considers the beading to be a plumber's trick, and Mr. Bligh Bond remarks : "As for the buttoned shafts, these also appear to me quite as likely to be characteristic of the earlier date, since we know that there are a good many instances of early woodwork (thirteenth and fourteenth century) which exhibit small shafts with turned caps and bands used as mullions; also the type of buttoned work on the Haresfield font seems much more like that seen on early furniture than that one observes as a seventeenth century ornament."

1 St. Mary Redcliffe, Wells, St. Mary Magdalen, Taunton, etc. 